\title{
A Conceptual Framework for a Building Integrated Photovoltaics (BIPV) Educative-Communication Approach
}

\author{
Daniel Efurosibina Attoye ${ }^{1, *(\mathbb{D})}$, Timothy O. Adekunle ${ }^{2}{ }^{\circledR}$, Kheira Anissa Tabet Aoul ${ }^{1}{ }^{(}$, \\ Ahmed Hassan ${ }^{1}$ (1) and Samuel Osekafore Attoye ${ }^{3}$ \\ 1 Department of Architectural Engineering, United Arab Emirates University (UAEU), P.O. Box 15551, \\ Al Ain 15258, UAE; kheira.anissa@uaeu.ac.ae (K.A.T.A.); ahmed.hassan@uaeu.ac.ae (A.H.) \\ 2 Department of Architecture, University of Hartford, 200 Bloomfield Avenue, West Hartford, CT 06117, USA; \\ adekunle@hartford.edu \\ 3 Department of Mechanical Engineering, Indiana University-Purdue University Indianapolis, 317-274-5555 \\ 420 University Blvd, Indianapolis, IN 46202, USA; soattoye@iu.edu \\ * Correspondence: 201590088@uaeu.ac.ae; Tel.: +971-53-971-6472
}

Received: 22 August 2018; Accepted: 10 October 2018; Published: 19 October 2018

\begin{abstract}
Global interest in Building Integrated Photovoltaics (BIPV) has grown following forecasts of a compound annual growth rate of $18.7 \%$ and a total of $5.4 \mathrm{GW}$ installed worldwide from 2013 to 2019. Although the BIPV technology has been in the public domain for the last three decades, its adoption has been hindered. Existing literature asserts that proper information and education at the proposal or early design stage is an important way of addressing adoption barriers. However, there is a lack of BIPV communication approaches for research, and market proposals that focus on clear information about its benefits. This has limited the adoption of BIPV.. Based on this, the present study aims to develop a conceptual framework for an educative-communication approach for presenting BIPV proposals to encourage its adoption. This is aimed at developing holistic research and market proposals which justify scholarly investigation and financial investment. Using a multiple case study investigation and Design Research Methodology (DRM) principles, the study developed an approach which combines core communication requirements, the pillars of sustainability and a hierarchical description of BIPV alongside its unique advantages. A two-step evaluation strategy involving an online pilot survey and a literature-based checklist, was used to validate the effectiveness of the developed approach. Our results show that understanding environmental and economic benefits was found to be significantly important to people who are likely adopters of BIPV $(p<0.05)$, making these benefits crucial drivers of adoption. Statistical significance was also found between those who do not know the benefits of using solar energy for electricity, and interest in knowing these benefits $(p<0.05)$. We thus conclude that proper communication of these benefits can safely be advanced as important facilitators of BIPV adoption. In general, this study elaborates the need and strategies for appropriate dissemination of innovative ideas to encourage and promote adoption of technological advancement for a sustainable global future.
\end{abstract}

Keywords: Building Integrated Photovoltaic (BIPV); barriers; sustainability; multi-functionality; proposal; educative-communication approach

\section{Introduction}

Innovation in the photovoltaic industry has spurred the growth of Building Integrated Photovoltaics (BIPV). BIPV refers to the use of photovoltaic (PV) devices to replace conventional building components of the building envelope, such as the roof, skylights or facades [1]. 
This technology brings a unique set of qualities and opportunities to the building industry such as on-site renewable energy generation, energy autonomy, and material multi-functionality. On-site power generation addresses the transmission and conversion losses of utility-scale photovoltaics with power generation close to the primary load [2-5]. BIPV also provides users with a degree of energy security and autonomy, and encourages reduced levels of energy consumption [6,7]. Conceptual and validated studies have verified BIPV energy output which reaches the Passivhaus threshold of $120 \mathrm{kWh} / \mathrm{m}^{2}$, thus capable of enabling the Zero Energy Building (ZEB) target [8]. As a multi-functional building component, it also allows for daylighting and view; serving as safety glass, a shading device or privacy screen [9-11]. Each component of the building skin -roofing, walls, glazing, cladding, and fenestrations; as well as other external devices provide opportunities for integrating PV into the building in various applications [12-16].

In another light, BIPV technology represents the opportunity for a triple advantage in architectural design. It harnesses solar energy, addresses some limitations of utility-scale PV and converts the building from an energy consumer to energy producer as a multi-functional component. In harnessing solar energy, it utilizes renewable energy from the sun which provides more energy in one hour than the all the people on earth require for a whole year [17,18]. It also provides decentralized on-site energy right next to the point of use, thus reducing transmission and conversion losses, as well as ancillary costs associated with utility-scale PV [2-5,19-21]. Additionally, it serves as a multifunctional energy-producing building component used for roofing, cladding, glazing or shading $[1,12,13]$.

The global BIPV market witnessed a 35\% growth between 2014 and 2015 from an estimated $1.5 \mathrm{GW}$ to $2.3 \mathrm{GW}$ [22]. However, the global contribution of BIPV to the energy capacity added by Solar PV in 2016 was 1\%-being about 3.4 GW of the total from Solar PV-about 303 GW [22-24]. Thus, though BIPV technology has multiple benefits and has been in public domain for the last three decades, its adoption rate in the built environment is limited. An overview of twelve studies on BIPV adoption [25-36] was carried out in a previous work [37]; from this, six major BIPV adoption barrier categories were identified. Most of these studies agree and specifically identify BIPV adoption barriers which relate to education/information [25-28,32], product, and project database [25-28], economy [26-30], industry [30-33], and management [25,29,30,33]. Among these, reported findings reflect that the impact of education linked with sufficient information and knowledge about BIPV is the most crucial [37]. Specifically, the review shows that, both within professional and public circles, there is a lack of sufficient knowledge on design, cost issues and multi-functional benefits from the environmental to economic to the social dimensions of BIPV adoption. Consequently, adoption of BIPV as a versatile renewable energy source is limited.

\subsection{Research Aim and Significance}

In light of the foregoing, this paper aims to fill this gap in the literature by developing a conceptual framework for an educative-communication approach to inform and facilitate adoption about BIPV. The duality and applicability of the intended approach may assist in strengthening its importance as an adoption driver by going beyond simply providing information (educative dimension) to communicating meaning (communication dimension). This stated significance of this study is driven by the need to increase BIPV adoption globally as a means towards harnessing its multifaceted benefits while reducing the negative impact of buildings on the built environment. This assertion is based on the fact that buildings are responsible for over $40 \%$ of the total annual global energy consumption, $10 \%$ of all CO2 emissions [38-40], 30-40\% of greenhouse gas emissions, $30-40 \%$ of solid waste generated and $20 \%$ of all water consumption [41]. These figures show that the building industry is in need of a strategy which reduces its negative environmental impact. In line with this, the unique advantage of BIPV is that it harnesses renewable energy from the sun and also potentially stems the negative impact of buildings on a global scale as it converts the building from energy consumers into energy producers [42]. 
Several strategic approaches have been developed to communicate the importance of solar technology and/or BIPV adoption. However, this research seeks to advance and develop a communication approach which adopts key concepts from related approaches, expands the core requirements based on literature and develops an improved case-specific solution. Our approach is specifically oriented towards facilitating initial proposal presentations on BIPV adoption to justify market investments and research investigations. From a market point of view, the need to justify financial investment cannot be overstated as companies are always concerned about the market feasibility of a product. Similarly, research investigations need to address both a research gap and a research need. Thus, BIPV proposals in both fields (market and research) need to be sufficiently justified and communicated in a manner which explains and warrants the required time and financial investments.

\subsection{Research Design}

To develop the proposed conceptual framework, we proceeded by conceiving the investigation as the first stage of developing a grounded approach and thus focused on a deductive overview of the related literature; next, the development of the approach, and finally its evaluation. The literature overview was carried out on topics inherently related when considering BIPV technology, added to this section was an outline of BIPV educational barriers to set the stage for clarifying the research objective. The method section involved a combination of case study methodology with the Design Research Methodology (DRM) by Blessing and Chakrabarti [43]. This section also adapted principles from $[44,45]$ to justify the procedure applied, and was framed to synthesize core requirements to aid the proposed design. Finally, we evaluated the developed approach in line with DRM principles. This was done using a pilot study on potential BIPV clients, and a checklist deduced from existing literature to verify if the approach meets both "market" and "research" expectations respectively. Figure 1 below shows the various stages of the research design with color codes for the respective steps; blue for the literature background, yellow for the method section and green for the evaluation section of the investigation.

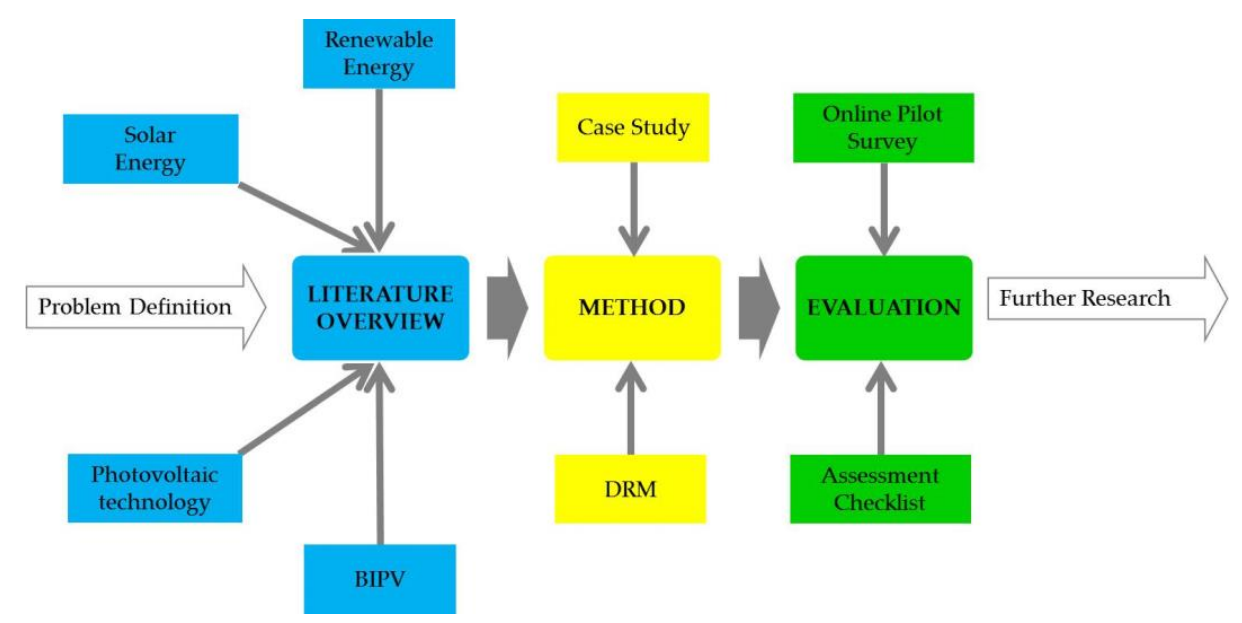

Figure 1. Research design.

\section{Research Background}

BIPV is an energy-producing building component which derives power from a renewable source (i.e., solar); it utilizes solar energy harnessed and converted into electricity by photovoltaic technology-via solar cells, which are integrated into the building envelope. At each level of mention as stated (i.e., renewable energy, solar energy, photovoltaics, and BIPV) significant research has been carried out in recent years. Energy production from Renewable Energy Systems (RES) is spreading but still represents a small part of the energy mix globally [46]. However, the simultaneous increase 
in energy demand and the negative impact of fossil fuels on the environment warrants the need for the development in this sector. A common thread between the existing studies on renewable energy, solar and photovoltaic technology is the identification of benefits, barriers, application, and future trends [47-50]. Research in these related areas suggests that key relationships can be traced and used to understand how the BIPV technology sits within the general body of research investigation relating to barriers and possible solutions.

Concerning renewable energy research, the authors of [47] assessed "limiting mechanisms" in this sector and identified the need for holistic cost comparisons between renewables and non-renewables as well as proper understanding of the ratio of energy produced to energy invested in forecast studies. The authors of [51] highlighted challenges and potential approaches towards the development of appropriate solutions for global renewable energy education initiatives. Among several findings, they noted a lack of structured curricula as a challenge, and thus suggested sufficient content in all renewable energy sources with local context emphasis as a desirable approach. About the attitudes of local communities towards investments in renewable energy projects, (i.e., adoption) a case study investigation showed that information and perceptions are behavioral determinants [46]. The authors asserted that a balance between economic, technical and environmental considerations in using RES would enhance more sustainable development towards future generations. To aid decision support for renewable technology and energy planning, the authors of [52] note the growing interest in flexible and user-friendly methods and a need for validation of results by "development of interactive decision support systems and application of fuzzy methods."

Other authors [48] highlight the fact that rapid growth in the field of solar technology, being a type of RES is marred by technical barriers such low solar cell efficiencies and performance of balance-of-systems (BOS) as well as economic and institutional obstacles. This persists even though some consider the sun as the most free and abundant renewable source [53] releasing $3.8 \times 1023 \mathrm{~kW} / \mathrm{s}$ [54] and providing in an hour, more energy than the annual total global energy demand $[17,18]$. Some researchers [55-57] also note that there is limited awareness about the potential benefits of the solar industry in rural regions and that technology, research, and policy are identified as major challenges [49]. With various unique solar technologies such as solar PV, solar thermal, and solar fuels technologies as well as concentrated solar power (CSP), it has been suggested that choice of type, should be based on the type of usage/demand and prevailing conditions [58]. Also, technical parameters such as tilt and azimuth angles need to be better understood via design simulation [59]. The authors of [60] suggest that a unified approach to continued research, engineering and manufacturing will need to be pursued for the full potential of solar energy to be realized. In other terms, it has also been suggested that multidisciplinary approaches, perspectives, and collaborations are required to resolve these said barriers with solar technology applications [49].

On the other hand, research and developmental progress in solar power generation have been made in areas of hardware development and testing towards efficiency maximization and cost minimization [50]. Challenges such as affordability, needed policies, appropriate system planning $[50,61]$ have warranted suggestions and survival strategies for PV technology [62] such as new developments, improvements and innovations [63,64]. In order to improve PV self-consumption, the authors of [65] noted that energy storage and load management, also called demand-side management (DSM) are needed considerations. To increase the participation of photovoltaic energy in the renewable energy, raising market awareness to its benefit has also been suggested [61].

The limitations mentioned above are inherent in related topics of interest when considering BIPV technology and are crucial. These topics form its intrinsic constitution and thus require active research and development to address them. The referenced studies suggest several crucial points, one being that there is a need for sufficient, credible and contextual information to be presented to stakeholders to aid adoption of the technology. This should also be synthesized and presented using flexible and user-friendly methods which embrace a multidisciplinary approach drawing from the environmental, economic and social dimensions. Besides the above, however, the BIPV technology also has its 
unique barriers and limiting factors as identified in several studies mentioned in the introduction. These barriers are in areas of education, product, economy, database, industry, and management with previous research identifying BIPV education/information awareness as the most crucial of these [37]. Seeing that the interposing barriers mentioned above (i.e., in line with RES, solar and PV) also identify information, awareness, and education as a need, this study seeks to address this challenge by the development of the proposed Educative-Communication Approach. The educative dimension provides contextual information, and the communication dimension is meant to facilitate interaction to inspire BIPV adoption.

\section{Education and Communication of BIPV as a Technological Innovation}

With the specific mention of BIPV educational barriers mentioned above, literature shows that both professional and public domains are affected. Specifically, findings from surveys on public educational barriers state various reasons such as a poor public understanding of cost perceptions of BIPV and financial benefit understanding $[29,33]$ and a lack of sufficient knowledge by clients and the public in general [26,33]. Also reported is a high negative perception of system price and costs associated with aesthetic BIPV options [33]. In 2017, a survey was conducted in Europe to identify educational needs to resolve this barrier [27]. The report identifies a dearth of university courses on BIPV and also identifies the lack, and thus the need for knowledge of product options, design strategies, performance and cost issues. Also refs. $[26,28,30]$ respectively report that a lack of sufficient technical knowledge, certified BIPV contractors available, and insufficient knowledge about BIPV system advantages, risk, and complexity exists. The lack of knowledge on how to ensure the most efficient choice of BIPV design has also been noted [31].

Having stated the above, providing education and information to aid BIPV proposals-market or research requires proper communication. It has been reported that "the successful design and realization of solar architecture-in general, relies upon the effective communication of its qualities in the development of a project" [35]. Solar energy systems are becoming more cost-efficient through continuing technological development [50,62]. However, the growth of these systems into a comprehensive and everyday solution, to the zenith of being a "natural choice for all projects" is consequent on the proper communication of the qualities of these systems [35]. Mastering the best balance between installed power, energy generation and aesthetic appearance of solar technology is not an easy task, and the lack of information will be decisive [66]. Communicating goals, information and idea sharing with stakeholders has been advocated as a means to facilitate a sufficient and mutual understanding. Indeed, it has been asserted that project goals, from inception to completion are facilitated via proper communication [35]. Given its multiple advantages earlier stated, planned and evaluated investment of BIPV, as well as the adoption of convincing approaches should therefore be encouraged. This will be needed to justify solar energy adoption in project proposals, especially as the energy solution and the use of solar energy are a significant part of the considerations when designing a building.

At present, the BIPV technological innovation is in a cycle of debate and development, which is, indeed, characteristic of all innovative ideas. This investigation presents the relevance of both educative/informative and communicative goals towards facilitating adoption as its theoretical underpinning based on referenced related literature. The "diffusion of innovation" theory by Everett Rogers has been reviewed [67] and it asserts that relative advantage (i.e., benefits) is the strongest predictor of the rate of adoption of an innovation. The term 'Relative Advantage' suggests the degree of perceived advantage or state of being better than existing options [68]. The authors of [69] carried out a detailed review of 20 innovation frameworks and conclude that determinants which potentially foster adoption include clarity and simplicity of use as well as improved benefit over existing options. They also assert that clear research evidence, cost-efficacy and feasibility, relating to expected benefits are also crucial drivers which advance the adoption of innovation. These theorists thus agree that 
educating and communicating benefits is a multi-disciplinary philosophy which is a potential driver of innovation adoption.

\section{Method}

As earlier stated, the method of investigation combines a case study and the DRM principles to carry out the design and development of the proposed approach, followed by an evaluation and review. This 3-phase approach is detailed in this section; representing the foundational and conceptual design process for the proposed approach.

\subsection{Phase 1: Case Study Investigation on BIPV Communication Approaches}

Following the categorization of case study typologies [44], we carried out a descriptive qualitative overview of multiple case studies. Several studies referenced below distinguish between single and multiple case studies. The consensus is that multiple-case studies generally enhance a stronger base for theory building [70], facilitate comparisons to elucidate whether an emergent finding is case-specific or subject-specific, i.e., replicated by several cases [71]. Other advantages include wider elaboration and exploration of research questions and theory [45]. General case study selection considerations from literature which guided our investigation include:

- Ability to reflect characteristics identified in the underlying theoretical background/propositions [44]

- Ability of the chosen cases to fit the purpose of the research [72]

- Ability to represent and exemplify the phenomenon of inquiry [72]

- Suitability for illuminating and extending relationships related to the investigation [45]

- Applicable for detailing and expanding logic among constructs of the study [45]

- Clear description of the existence of a phenomenon [73]

To address the theoretical sampling complexity inherent in multiple cases studies, existing literature suggests that the choice is based less on case uniqueness but more on the contributory relevance, agreeing with theoretical propositions and development within the set of cases [44,45]. Based on these requirements, we reviewed related studies on BIPV adoption, and we identified three (3) studies which focus on developed approaches to communicate BIPV. These include the International Energy Agency-IEA Task 41-SubTask C three-stage approach from client to design team to design-communication tools [74], the European-based use of "an ambitious demonstration project portfolio" [75], and an Architectural Integration Qualities (AIQ) model which initiates and focuses discussions on preferences for architectural integration of energy-producing solar shading [76]. The sub-sections which follow state an overview of these studies used to deduce core requirements for the proposed approach as a starting point for the design process.

\subsubsection{The IEA TASK 41 Communication Guide}

IEA Task 41, "Solar Energy and Architecture" focused its subtask C on developing communication guidelines and delivered a 3-step approach for achieving this goal. These steps, laid out as sections in the Guide [74], can occur continuously during design development (Figure 2). Indeed, the report posits that one of the main reasons for not adopting solar energy in projects today is the lack of client confidence in the field. It was suggested that investors do not generally adopt solar energy in projects due to lack of knowledge, experience, and accessible information about benefits, risks, and system characteristics.

The first section of the guideline focuses on strategies to convince clients to request solar building projects. It includes recommendations for identifying client goals and motivations, and important integration considerations for common project types. Section two addresses communication strategies at the design and construction team level. It suggests techniques for "anchoring solar energy strategies within the project team" and communication strategies with manufacturers, with added content for strategies within a design-build process. Section three discusses tools for communication and design 
development with included national references to design guidelines for solar energy and architecture within the Task's participating countries. This case study provides a holistic, macro-level consideration of the BIPV communication approach.

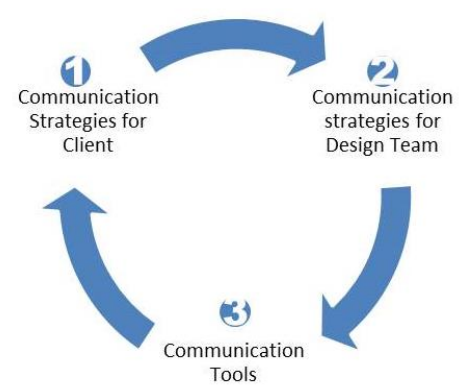

Figure 2. International Energy Agency (IEA) Task 41 three-step approach. Source: Adapted from Ref. [74].

\subsubsection{The PVSITES Project}

The PVSITES project began in 2016 as a joint multi-disciplinary European approach to drive large market deployment of BIPV technology. The goal is to demonstrate "an ambitious portfolio of building-integrated solar technologies and systems." This was towards giving a definite and professionally reliable answer to the market requirements pre-identified by the industrial members of the consortium. It focuses on high impact demonstration and dissemination actions to be executed using cost-effective renewable generation, reduction of energy demands and smart energy management $[75,77]$.

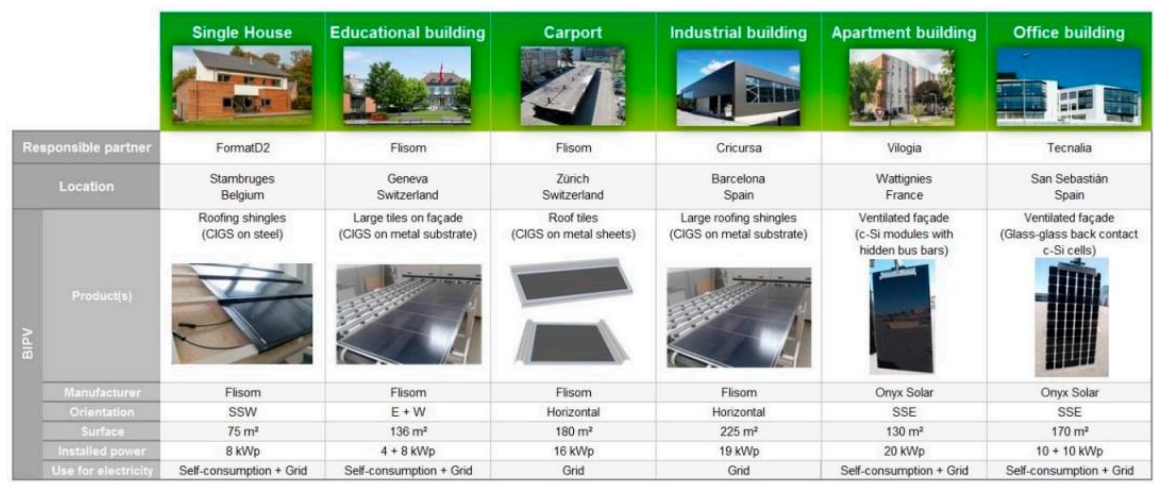

Plate 1. Overview of PVSITES' demonstration projects. Source: [75].

The authors of [75] argue that the gradual acceptance of BIPV installations by stakeholders requires the use of high visibility showcase projects. In the PVSITES demo cases, the proposed module, grid interface, and energy management technologies are demonstrated in at least six real buildings covering different EU electricity markets and climates, building uses (residential, industrial, commercial) in new buildings and retrofit projects. These are designed to highlight different architectural integration strategies, allow for easy replication and adaptation. The buildings showcased in Plate 1 above, show a varied range of innovative BIPV products-roof shingles, roof and façade tiles, and a ventilated façade - in different European locations such as Belgium, Switzerland, Spain, and France [65]. This case study provides a design-focused, macro-level consideration of the BIPV communication approach facilitated by completed projects.

\subsubsection{The AIQ-Model}

This case study focuses on the development a tool to aid communication on the subject of "energy-producing solar shading" as this relates to a type of BIPV (i.e., BIPV shading devices) [76]. It is 
based on the findings of other authors who argue that BIPV design is in need of a multi-disciplinary communication language or tool $[10,64]$. Therefore, an approach to evaluate architectural integration qualities was developed to communicate the aesthetic values of such systems. The AIQ-Tool developed is visualized as a triangle where corners represent geometry, materiality and detailing; to evaluate the degree (poor, fair or good) to which solar shading system fits with the overall building design.

The authors report that the AIQ-Tool helped the surveyed participants of a test focus group to articulate architectural integration and gave rise to positive discussions. Also, it was observed that although architects had the best conditions to use the tool, the discussions were facilitated by other professions. A critique of the tool as presented by its developers is its limitation to "external integration and aesthetics". They state that this does not embrace the inter-disciplinary perspectives of solar building design which requires multi-functional energy planning as perceived by different disciplines. This case study asserts the need for an expanded consideration across disciplines to provide an inclusive and holistic BIPV communication approach.

\subsubsection{Case Study Deductions}

To extract deductions from these cases and achieve some preliminary analysis, we aimed at a synthesis of the characteristics based on analytical generalization following "replication logic". This was done in agreement with literature recommendations "to generalize theoretical propositions and not a population as in statistical research [44]. Apart from guiding an identification of core requirements for the proposed approach, the synthesis was also to provide suggestions and show limitations to avoid in the design of the approach. The following list deduced represents applicable key points, used in the reference cases to boost proper communication before, during or after the design phase.

1. Provide accessible information about BIPV benefits and risks [74,75]

2. Convince clients to request BIPV $[74,75]$

3. Anchor solar energy strategies within the project [74]

4. Maximize tools or models for communication [74,76]

5. Apply a continuous communication process [74]

6. Utilize high impact demonstration projects [75]

7. Apply a multi-disciplinary communication tool $[75,76]$

These seven points are used as a guide to the design and as part of the strategy to review the developed educative-communication approach in the evaluation section. This was done in addition to other associated requirements for addressing BIPV barriers in tandem with its RES-Solar-PV roots extracted from the literature section. The combined requirements were distilled into an evaluation checklist in the final section of this investigation to assess the effectiveness of the developed approach.

\subsection{Phase 2: Design of the Approach}

The DRM approach by [43] is a multi-disciplinary guide which provides a framework for design research, development of the research argumentation, guidelines for research planning and methods. Within the approach, the "Development of Support" method (Type 3) is recommended for use when the existing literature review provides sufficient guide to start the design development. As this scenario matches our present investigation, we adopted this 'research type'. The term "support" in this case refers to an aid used to improve design such as strategies or approaches and the process for introducing methods. In our research scenario, existing support options for BIPV communication to improve chances of adoption are present but limited and case-specific proposal presentations are not prioritized. Therefore, we opted to integrate the principles of the systematic Prescriptive Study (PS) which is recommended for use when the existing support is insufficient.

Our adaptation of the PS is justified by the flexible and adaptable nature of the DRM principles to match project requirements, and covers three core areas of task clarification, conceptualization, 
and preliminary evaluation. Our introduction and literature overview provided an awareness of the problem statement to clarify the design task (i.e., task clarification). For the conceptualization stage of the conceptual framework intended, the case study in Section 3.1 provided the core requirements for the support. We thus, required a firm concept, based on the DRM system to frame the design of the proposed approach. The DRM system allows for assumptions and experience to guide this selection which in generic terms ought to satisfy applicability, adaptability and generalizability to the task under review. In the current era of sustainable development, decision making in energy projects requires consideration of technical, economic, environmental and social impacts [51,78-81]. The process of energy planning under this largely interdisciplinary scenario is thus, often complicated due to the involvement of these multiple benchmarks [82]. In line with these considerations, we required a broad-based multi-disciplinary concept. We thus, chose the pillars of sustainability and a redefinition of the BIPV structure as our theoretical driving concept. The following section clearly explains how this informs the process of designing our conceptual framework.

\subsubsection{Step 1: Pillars of Sustainability as the 1st Driving Concept}

The mainstream theory for sustainability has become the idea of three pillars (3Ps) namely: economic, social and environmental sustainability [83]. Although there are other cultural and political aspects, these do not form the core of our focus in this investigation. The pillars of sustainability follow the concept that every sustainable approach or idea must provide benefits regarding the cost, social impact, and ecological impact or carbon footprint. The three pillars are interwoven and have been explained in different ways to highlight the importance of sustainability and the three major players -people, planet, and profits. Adopted by the General Assembly of the 2002 and 2005 World Summit on Sustainable Development, these three components-economic development, social development, and environmental protection-are presented as interdependent and mutually reinforcing pillars $[84,85]$. Today, these pillars are expressed and discussed extensively across various governmental, professional and commercial circles; influencing concepts like the triple bottom line in sustainable urbanism and other aspects of the sustainable built environment. They respectively relate to continued support for a defined economic production, maintenance of social well-being, and ability to ensure responsible use of renewable resources to curb non-renewable resource depletion.

A few extra points to note; environmental sustainability suggests that the framework must promote the overall well-being of people. For the social sustainability, the concept must maintain equity while economic sustainability ensures the framework is not only innovative but cost-effective. Based on the definitions of the pillars, it is essential to state that any connecting framework or approach must meet the requirements highlighted in the descriptions. As such, our investigation agrees that for BIPV, the framework for research and market proposals must satisfy the crucial requirements for the pillars of sustainability. Also, the integration of the pillars for the development of a framework must provide a truly sustainable design or development that will make the world a better place.

\subsubsection{Step 2: BIPV Triple Advantage and Hierarchy of Form as the 2nd Driving Concept}

A detailed understanding of BIPV viz-a-viz, a structural breakdown of its constituents, has been suggested [86]. Reference is made to the elemental and compositional dimensions; the former relates to specifics such as the cell technology, cells shape, module design, and arrangement. The latter refers to the building function and type of product. In addition to this descriptive Index, a holistic understanding of BIPV can encompass the hierarchy of BIPV origins and form. The hierarchical composition of BIPV earlier mentioned in the introduction refers to it as a building component, next as type of PV technology; then as a strategy which harnesses solar energy to generate electricity. Further, solar energy is itself a renewable source of energy which assists to reduce the use of non-renewables and stem the rate of global environmental pollution. This breakdown forms the philosophical idea put forward as a part of the theoretical concept for this investigation. It portrays a broader perspective of what BIPV represents and may help to appreciate its relevance to society and 
facilitate its adoption. The ability to communicate relevance and importance within a proposal context, at each aspect of this chain represents a holistic understanding of the importance of BIPV. Figure 3 shows a diagrammatic illustration of the BIPV-PV-Solar-Renewable chain.

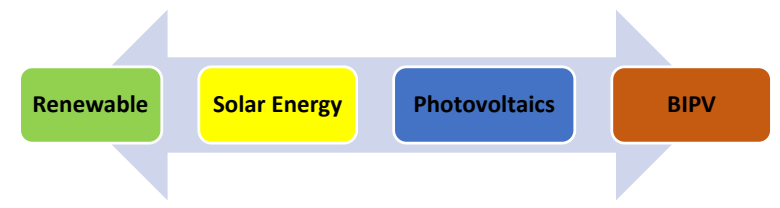

Figure 3. Building Integrated Photovoltaics (BIPV) Hierarchy of Form. Source: Authors.

\subsubsection{Step 3: The BIPV-3P Matrix}

For the final stage of the "Approach development" we designed an integrated matrix which presents a simple juxtaposition of the BIPV hierarchy of form with the 3 Pillars of sustainability. This leads to a comparison of the four components of the BIPV-PV-Solar-Renewable chain with the Environmental-Economic-Social Pillars. In this comparison, the BIPV technology/proposal/project/is discussed at each level of its hierarchy based on associated environmental, social or economic benefits. Added to the approach is the design dimension to simulate the intrinsic architectural orientation of BIPV. Figure 4 below shows the diagrammatic color-coded representation of the matrix. Each cell in the matrix corresponds to the required information at each level of the BIPV Hierarchy based on its 3P benefits. The grid format selected assists in a structured and systematic approach to present the facts required to justify the project/proposal objectives and benefits.

The matrix brings together all the work done so far in a singular figurative depiction and forms the illustrative representation of the conceptual framework. Its visual depiction can be modified based on the objectives of the proposal in view to match the kind of audience being discussed with. However, its objective and intent remain holistic and inclusive of the focused findings from literature which relate to specifics along the BIPV-Solar-PV-Renewable chain. It also integrates the core requirements deduced from the case study and follows the systematic approach recommended by the DRM principles applied.

\begin{tabular}{|c|c|c|c|c|}
\hline $\begin{array}{c}\text { BIPV-3P } \\
\text { MATRIX }\end{array}$ & Environmental & Economy & Social & Design \\
\hline \multirow{2}{*}{ RENEWABLE } & 1 & 2 & 3 & 4 \\
\cline { 2 - 7 } & 5 & 6 & 7 & 8 \\
\hline \multirow{2}{*}{ SOLAR } & 9 & 10 & 11 & 12 \\
\hline
\end{tabular}

Figure 4. BIPV-3P Matrix. Source: Authors.

\subsection{Phase 3: Evaluation}

As earlier stated, in agreement with standard project planning and the DRM principles, we carried put an evaluation to review and if needed, improve the developed conceptual framework. To achieve this preliminary evaluation; two steps were taken; one to check its effectiveness towards actually facilitating the adoption of BIPV, the other to check its agreement with recommendations from literature. The first step was an online pilot survey redefined as a prospective user experience (UX) survey; the second, the use of a "Case Study Deductions Checklist" developed from the literature section. Both strategies were conceived and carried out as a part of this research, and the results are summarized below. 


\subsubsection{Pilot Survey: User Experience (UX) Format}

User Experience (UX) is defined as “a person's perceptions and responses that result from the use or anticipated use of a product, system or service" [87]. The authors of [88] also describe UX as "a consequence of a user's internal state (e.g., predispositions and expectations), the characteristics of the designed system (e.g., complexity, usability) and the context within which the interaction occurs". UX research thus allows investigators to carry out qualitative research while studying user behavior-actual or anticipated. Following our earlier description, one frame of reference (i.e., driving concept) used in this investigation to develop the approach is the "pillars of sustainability", i.e., 3P. This study anticipated a UX survey as a part of its evaluation of the conceptual framework while asserting a scholastic argument. This argument, advanced in this study is that persons who have an understanding of these 3P benefits/dimensions of BIPV will likely be positively disposed towards its adoption. This assumption agrees with several studies [25-27] and is also based on the innovations theories earlier discussed. Following this, we considered it logical to facilitate a means of engaging public feedback to evaluate the developed approach. To achieve this, a pilot UX-type survey was run on the internet for one week (10-17 June 2018). It was randomly deployed via social media-specifically Facebook and WhatsApp, with the questions prepared using Google Forms. Sixty-nine (69) responses were received, none were invalid, and all were used in the analysis. The objective of the survey was to confirm if the developed approach was indeed able to encourage BIPV adoption. It was thus designed to find out public opinion about electricity for home/office/school using solar panels as a part of the building. In statistical considerations, we also sought to investigate if there is a significant relationship between knowledge of BIPV benefits and the decision to adopt BIPV to justify the theoretical position of this investigation.

For clarity, the questions were designed to ensure proper understanding by both professionals and non-professionals. As such, technical details were redefined in simple everyday terms as explained below. The 3P concepts towards BIPV benefits i.e., environmental, economic and social were simplified; "environmental benefits" was simply framed as "helping the environment", "economic benefits" as "saving money", and "social benefits" as "higher social status and recognition". However, to ensure a holistic representation of these benefits, and guarantee that related aspects were not omitted, respondents were allowed to state any benefit they also considered important to adopting BIPV. In general, the underlying assumption of the simulated UX survey is that if a respondent considered that a benefit is important, then it has a potential impact on their decision to adopt BIPV. The list that follows is the results of the survey for each of the three questions, followed by a brief analysis of the results.

\section{Question 1: Do you know the benefits of using solar energy for electricity?}

The purpose of this question was to introduce and affirm our subject to the respondent, as well as establish a basis for further inquiry. It was framed to determine if the respondent was aware of the concept and availability of solar energy as a renewable energy system. A "yes" or "no" answer was provided to the respondents. The survey did not consider an "indifferent" or "no answer" option regarding this question as knowledge, not opinion was required at this point. From the results, over $95 \%$ (66 respondents) chose the option showing they had an understanding of the benefits of solar energy as a source of power. Only about $4 \%$ selected the option stating they did not know the merits of solar energy. This suggests a high level of awareness of the sustainable characteristic of solar energy amongst the respondents. While the $95 \%$ represents the group of persons who are considered "likely to adopt BIPV" based on the knowledge about its benefits, $4 \%$ are "unlikely to adopt". This characteristic of these groups makes for significant importance to this study and is later discussed further. 
2. Question 2: Which of these benefits is most important to you when deciding to use solar energy for electricity?

Respondents were asked to present their perceived importance of solar energy benefits. A multiple-choice format presented possible benefits relating to the 3P concept used to develop the approach. These were, helping the environment, better building design, saving money, higher social status and recognition. Respondents were permitted to select more than one option or add to the list.

Figure 5 above shows that over $81 \%$ ( 54 respondents) felt that solar energy was beneficial for two main reasons; firstly, by using it, they are helping the environment and secondly saving money. $24 \%$ (16 respondents) noted that better building design was a desirable benefit. Only about $5 \%$ felt all benefits were significant, and only about $2 \%$ ( 1 respondent) felt a higher social status and recognition was an important benefit. Six respondents (9\%) mentioned other specific reasons they would consider, but on closer examination, they mainly relate to design, environmental, and social issues already listed.

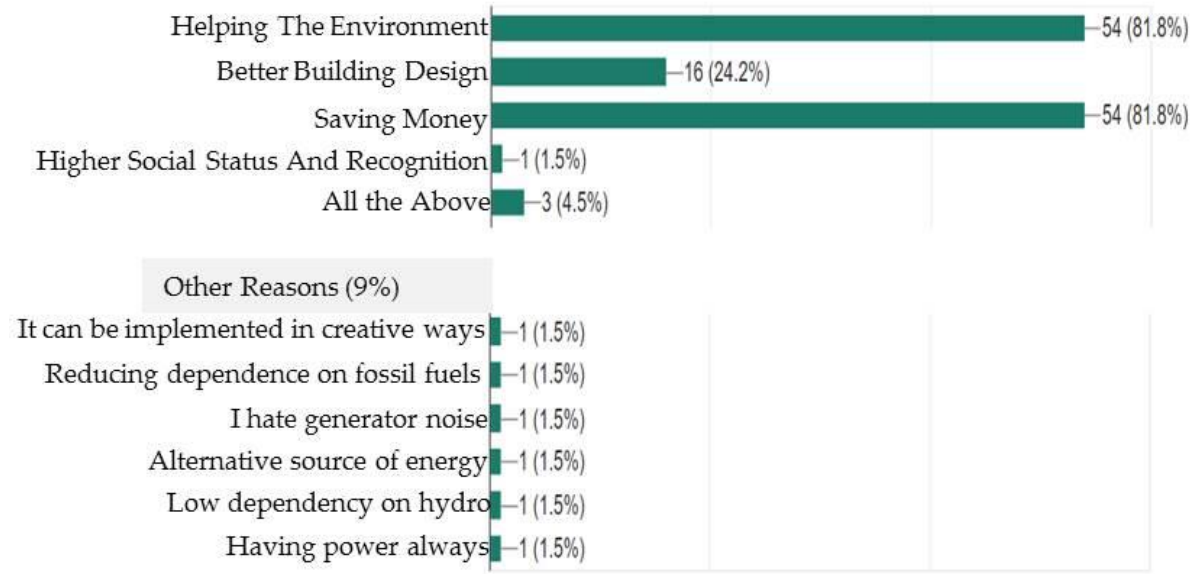

Figure 5. Responses to Question 2.

3. Question 3: Will you like to know these benefits?

This question was specifically reserved for respondents who answered: "NO" to question 1 ("do you know the benefits of using solar energy for electricity"?). This question was to identify if they desired to increase their knowledge of the merits of solar energy. All the three respondents $(100 \%)$ who answered "NO" in question 1 answered in the affirmative to this question (i.e., they will like to know these benefits).

Further statistical analysis of the pilot-shown in Table 1 below-revealed the mean values of Questions 1 to 3. The table shows the standard deviation values, sample variances, level of confidence for the variables. A significance was found between the respondents that did not know the benefits of using solar energy for electricity and would like to know the benefits $(p<0.05)$. Regarding Question 3 , the statistical analysis considered the responses; the results showed the average respondents considered helping the environment and saving money as the most crucial benefits when deciding the to use the solar energy for electricity. A relationship was therefore found between the respondents that understand the benefits of using solar energy for electricity and the respondents that selected helping the environment and saving money $(p<0.05)$. The import of this relationship shows that understanding environmental and economic benefits was found to be significantly important to people who are likely adopters of BIPV, making these benefits crucial drivers of adoption. 
Table 1. Mean, standard deviation, variable, and level of confidence for the pilot survey.

\begin{tabular}{|c|c|c|c|c|c|}
\hline Questions/Variables & $\begin{array}{c}\text { Number of } \\
\text { Respondents }\end{array}$ & Mean & $\begin{array}{c}\text { Standard } \\
\text { Deviation }\end{array}$ & $\begin{array}{c}\text { Sample } \\
\text { Variance }\end{array}$ & $\begin{array}{c}\text { Level of } \\
\text { Confidence at } 95 \%\end{array}$ \\
\hline $\begin{array}{l}\text { Q1: Do you know the benefits of using } \\
\text { solar energy for electricity? } \\
\text { Note: } 1-\text { Yes, } 2-\text { No }\end{array}$ & 69 & 1.0435 & 0.02473 & 0.0422 & $p<0.05$ \\
\hline $\begin{array}{l}\text { Q2: Will you like to know } \\
\text { these benefits? } \\
\text { Note: } 1-\text { Yes; } 2-\text { No }\end{array}$ & 69 & 1.9565 & 0.02054 & 0.04219 & $p<0.05$ \\
\hline $\begin{array}{l}\text { Q3: Which of these benefits is most } \\
\text { important to you when deciding to use } \\
\text { solar energy for electricity? } \\
\text { (You can select more than one) }\end{array}$ & 69 & 7.4559 & 0.4377 & 13.0279 & $\begin{array}{l}\text { The overall } p \text {-value } \\
\text { is greater than } 0.05\end{array}$ \\
\hline \multicolumn{6}{|c|}{$\begin{array}{l}\text { Note: Q3: 1-Helping the environment; 2-Better building design; 3-Saving money; 4-Higher social status and values; } 5 \text {-All of the } \\
\text { above; 6-Other reasons; 7-Helping the environment; Saving money; 8-Better building design; Saving money; 9-Helping the } \\
\text { environment; Better building design; Saving money; 10-Helping the environment; Better building design; Other reasons; } \\
\text { 11-Saving money; Other reasons; 12-Helping the environment; Other reasons; } 13 \text {-Helping the environment; Better building } \\
\text { design; 14-Helping the environment; Saving money; All of the above; 15-Helping the environment; Saving money; Other reasons }\end{array}$} \\
\hline
\end{tabular}

The results of the pilot survey show that most of the respondents know the benefits of using solar energy for electricity as part of the building. Also, environmental and economic benefits are considered most significant and social benefits less important by respondents interested in adopting BIPV. For the few who do not know the benefits of using solar for electricity, they were all interested in learning. Based on these findings, we tentatively conclude that since the approach provides copious information about environmental and economic benefits, it will potentially encourage adoption-at least for the respondents of the survey.

\subsubsection{Case Study Deductions Checklist}

The second evaluation strategy was a checklist developed to review the features of the BIPV communication approach developed based on the core requirements deduced from the case study section. This checklist also combines deductions and extrapolations from existing literature which describe requirements for proper BIPV communication. For each item on the Checklist, a "Yes" or "No" is given based on the structure and contents of the developed approach (See Table 2). A remarks column is also provided to give extra information as it relates to each specific requirement.

This checklist does not intend to cover all the aspects and requirements for BIPV communication. However, it satisfies certain crucial points which have been satisfied by the approach developed. These include the following:

- It helps to present the important features of the developed approach

- It serves as a means of evaluating the effectiveness of the approach and any other of the same basic requirement, format or approach

- It establishes an agreement between requirements in literature deduced from established projects and the features of the approach

- It confirms that the goal of the investigation to facilitate case-specific and contextual communication on BIPV has been achieved.

- It proves that the approach is research-based and thus a credible means of communicating benefits of a BIPV proposal. 
Table 2. Checklist for a BIPV communication approach. Source: Authors.

\begin{tabular}{|c|c|c|c|c|}
\hline & Checklist & Yes & No & Remark \\
\hline 1. & $\begin{array}{l}\text { Provide accessible information about } \\
\text { BIPV benefits and risks }[74,75]\end{array}$ & v & & $\begin{array}{l}\text { The approach can be used to highlight BIPV benefits as well as benefits of } \\
\text { RES, solar and PV. The information provided can also be used to assess and } \\
\text { compare with other sources of energy to develop a comparative or risk } \\
\text { assessment plan. }\end{array}$ \\
\hline 2. & $\begin{array}{l}\text { Convince clients to request } \\
\text { BIPV }[74,75]\end{array}$ & & & $\begin{array}{l}\text { The approach is based on a theoretical background which advances } \\
\text { communication as a means to advance adoption. It also provides } \\
\text { information which can be used to inform and educate clients on the merits } \\
\text { of BIPV adoption. }\end{array}$ \\
\hline 3. & $\begin{array}{c}\text { Anchor solar energy strategies within } \\
\text { the project [74] }\end{array}$ & & & $\begin{array}{l}\text { To enhance understanding and representation of solar energy strategies, } \\
\text { the approach anchors BIPV within a specific context for each proposal. } \\
\text { It starts out general but ends with very explicit information on the } \\
\text { project proposal. }\end{array}$ \\
\hline 4. & $\begin{array}{l}\text { Maximize tools or models for } \\
\text { communication }[74,76]\end{array}$ & & & $\begin{array}{l}\text { With a simple tabulated interface, the approach drives communication } \\
\text { which is guided by a sequential presentation of relevant facts. Adapting } \\
\text { this format to a digital interface is the next phase of its implementation. }\end{array}$ \\
\hline 5. & $\begin{array}{l}\text { Apply a continuous communication } \\
\text { process [74] }\end{array}$ & & & $\begin{array}{l}\text { By addressing multiple concerns; environmental, economic, social and } \\
\text { design, the approach covers the various aspects of building design from } \\
\text { conceptualization to completion. The matrix format may also guide review } \\
\text { during iterative changes in the proposal as it shows hierarchy and } \\
\text { relationship between columns and rows }\end{array}$ \\
\hline 6. & $\begin{array}{l}\text { Utilize high impact demonstration } \\
\text { projects [75] }\end{array}$ & & $x$ & $\begin{array}{l}\text { Although the approach can be applied to a wide range of projects } \\
\text { including small, medium and large-scale; it does not directly represent a } \\
\text { demonstration project. }\end{array}$ \\
\hline 7. & $\begin{array}{l}\text { Apply a multi-disciplinary } \\
\text { communication tool }[75,76]\end{array}$ & & & $\begin{array}{l}\text { Drawing from the multi-disciplinary nature of the BIPV technology, } \\
\text { the approach attempts to show aspects and concerns of interacting } \\
\text { disciplines. This can aid team building and brainstorming, and validate the } \\
\text { need for each professional within the team. }\end{array}$ \\
\hline 8. & Ratio of Energy [47] & & & $\begin{array}{l}\text { The approach can assist to present a relative comparison between energy } \\
\text { generated from BIPV and other energy sources to aid decision making } \\
\text { and investment }\end{array}$ \\
\hline 9. & Local context emphasis $[50,75]$ & & & $\begin{array}{l}\text { The primary focus of the cells relating to the BIPV system is specifically } \\
\text { and locally contextualized to the project under review. The information can } \\
\text { be used to compare various projects and inform management decisions }\end{array}$ \\
\hline 10. & $\begin{array}{l}\text { Balance between economic, technical } \\
\text { and environmental } \\
\text { considerations [45] }\end{array}$ & $\checkmark$ & & $\begin{array}{l}\text { By using the pillars of sustainability as a driving concept, the approach } \\
\text { presents a balance between these interrelated aspects and suggests that } \\
\text { extended input can be made to show specific data within each of } \\
\text { these considerations. }\end{array}$ \\
\hline 11. & $\begin{array}{l}\text { Flexible and User-Friendly } \\
\text { Methods }[51,76]\end{array}$ & $v$ & & $\begin{array}{l}\text { The simple matrix format assists non-professional to understand technical } \\
\text { information without complex presentation. It also clearly utilizes a } \\
\text { symbolic vertical and horizontal format to suggest the relationship } \\
\text { between these related issues to facilitate planning. }\end{array}$ \\
\hline
\end{tabular}

\section{Discussion}

The developed matrix is divided into a set of rows and columns to communicate the proposal/project idea. The information contained by detailing the 3P section of BIPV hierarchy 1 to 3 (i.e., Renewable, Solar and Photovoltaic aspects) is fundamentally similar for all projects (Cells 1 to 12). However, discussing it contextually can not only be different, but also potentially presents better relevance and aids understanding. For example, Renewable Energy (BIPV Hierarchy 1) has economic benefits (Cell 2) which are ultimately based on regional policies. As such, this information will differ for projects in separate geographical locations and consequently impact the contents of the matrix. BIPV Hierarchy 4 (Cell 13-16) is the core of the proposal, and the 3P outline should be discussed at two levels; firstly, the benefits of BIPV as an energy source and secondly, as a building component. To provide a better understanding of the matrix, crucial information required for communicating a BIPV project proposal for the sixteen cells has been outlined below (See Table 3). The list of suggested contents is aligned with the $3 \mathrm{P}$ columns on the matrix. However, this guide is not exhaustive, but rather, a list to showcase and justify the objective of the approach. Similar questions should be added to facilitate contextual and holistic potentials based on unique characteristics of individual proposals. For each of these cells, information is to be provided which is specific to the project proposal, with the background facts on the 3P benefits of renewable, solar and PV hierarchies. This matrix is flexible and can be presented as it is, or modified based on the specifics of the proposal. Although all the cells need not be filled, a general introduction of the BIPV hierarchy following the suggested chain can assist to develop a strong presentation to justify market/financial investments and research investigation. 
Table 3. Suggested contents of the BIPV-3P Matrix. Source: Authors.

\begin{tabular}{|c|c|}
\hline $\begin{array}{c}\text { Cells } \\
\text { Cells } 1 \text { to } 12\end{array}$ & $\begin{array}{l}\text { Suggested Content } \\
\text { BIPV Hierarchy } 1 \text { to } 3\end{array}$ \\
\hline $\begin{array}{l}\text { Cell 1: Environmental } \\
\text { benefits of Renewables }\end{array}$ & $\begin{array}{l}\text { - } \quad \text { State cumulative percentage/amount in tons of reduction of carbon emissions in the region } \\
\text { - State accrued benefits in wildlife conservation and human preservation (or related interest to sponsor) }\end{array}$ \\
\hline $\begin{array}{l}\text { Cell 2: Economic benefits } \\
\text { of Renewables }\end{array}$ & $\begin{array}{l}\text { - } \quad \text { State fuel and maintenance cost savings compared with non-renewable energy sources } \\
\text { - } \quad \text { State marketability of free natural resources }\end{array}$ \\
\hline $\begin{array}{l}\text { Cell 3: Social benefits of } \\
\text { Renewables }\end{array}$ & $\begin{array}{l}\text { - State the potential reduction in the Social Cost of Carbon (SCC) associated with similar energy output from a fossil } \\
\text { fuel power plant } \\
\text { - State accrued benefits of replacing fossil energy sources, and other points such as international recognition } \\
\text { and accountability }\end{array}$ \\
\hline $\begin{array}{l}\text { Cell 4: Design benefits of } \\
\text { Renewables }\end{array}$ & $\begin{array}{l}\text { - } \quad \text { Highlight adopting buildings as a free-standing support medium for Building Integrated Renewables } \\
\text { - } \quad \text { State potential visual impact on energy awareness on the residents in the region }\end{array}$ \\
\hline $\begin{array}{l}\text { Cell 5: Environmental } \\
\text { benefits of Solar Energy }\end{array}$ & $\begin{array}{ll}\text { - } & \text { State cumulative percentage/amount in tons of reduction in carbon emissions in the region } \\
\text { - } & \text { State reduction in pollution (e.g., noise) during use compared to fossil fuel energy generation }\end{array}$ \\
\hline $\begin{array}{l}\text { Cell 6: Economic benefits } \\
\text { of Solar Energy }\end{array}$ & $\begin{array}{ll}\text { - } & \text { State energy security benefits and autonomy; and advantages of a constant source of fuel } \\
\text { - } & \text { State flexibility and adaptability for basic household use and advanced technological applications }\end{array}$ \\
\hline $\begin{array}{l}\text { Cell 7: Social benefits of } \\
\text { Solar Energy }\end{array}$ & $\begin{array}{l}\text { - } \quad \text { State potential to advance global energy reduction targets and advocacy/image recognition } \\
\text { - } \quad \text { State potential for labor employment and other corporate social responsibilities }\end{array}$ \\
\hline $\begin{array}{l}\text { Cell 8: Design benefits of } \\
\text { Solar Energy }\end{array}$ & $\begin{array}{l}\text { - } \quad \text { State passive opportunities such as daylighting, along with sustainability benefits } \\
\text { - } \quad \text { State active opportunities such as photovoltaics, along with sustainability innovations }\end{array}$ \\
\hline $\begin{array}{l}\text { Cell 9: Environmental } \\
\text { benefits of Photovoltaics }\end{array}$ & $\begin{array}{l}\text { - State cumulative percentage/amount in tons of reduction of carbon emissions in the region } \\
\text { - } \quad \text { State advantages of a constant source of fuel relating to the reduced recurrent need for fuel harvesting }\end{array}$ \\
\hline $\begin{array}{l}\text { Cell 10: Economic } \\
\text { benefits of Photovoltaics }\end{array}$ & $\begin{array}{l}\text { - State comparative long-term cost benefits compared with other energy sources relating to maintenance } \\
\text { - } \quad \text { State savings in cost of fuel compared to other energy sources }\end{array}$ \\
\hline $\begin{array}{l}\text { Cell 11: Social benefits of } \\
\text { Photovoltaics }\end{array}$ & $\begin{array}{l}\text { - } \quad \text { State investment as a form of social responsibility towards a global sustainable future } \\
\text { - } \quad \text { State labor employment, advocacy, and support for the industry }\end{array}$ \\
\hline $\begin{array}{l}\text { Cell 12: Design benefits of } \\
\text { Photovoltaics }\end{array}$ & $\begin{array}{l}\text { - State opportunities as a building integrated or building applied system } \\
\text { - State technological growth as a sign of the global shift towards harmony with the architectural design and } \\
\text { opportunity for clean energy from buildings }\end{array}$ \\
\hline Cell 13a-16a & BIPV Hierarchy 4: as an Energy Source \\
\hline $\begin{array}{l}\text { Cell 13a: Environmental } \\
\text { Benefits }\end{array}$ & $\begin{array}{l}\text { - } \quad \text { State how much the proposal reduces } \mathrm{CO}_{2} \text { emission } \\
\text { - } \quad \text { State how much land is saved compared to utility-scale PV based on expected power output } \\
\text { - State the number of trees saved by using BIPV in the project based on similar expected power output from a } \\
\text { utility-scale PV plant }\end{array}$ \\
\hline $\begin{array}{l}\text { Cell 14a: Economic } \\
\text { Benefits }\end{array}$ & $\begin{array}{ll} & \text { State the amount of savings in labor cost } \\
\text { - } & \text { State the amount of savings in infrastructure cost compared to utility-scale PV based on expected power output } \\
\text { - } & \text { State the cost savings in land purchase compared to a utility-scale project of the same expected power output }\end{array}$ \\
\hline Cell 15a: Social Benefits & $\begin{array}{ll}\text { - } & \text { State the visibility of the project to the public } \\
\text { - } & \text { State opportunities for educating the public } \\
\text { - } & \text { State potentials to achieve significant recognition by prioritizing on regional /international sustainability ratings } \\
\text { such as LEED (Leadership in Energy and Environmental Design) }\end{array}$ \\
\hline Cell 16a: Design Benefits & $\begin{array}{ll}- & \text { State the amount of energy produced } \\
\text { - } & \text { State the amount of energy saved compared to use of non-renewable sources } \\
\text { - } & \text { State the benefits of energy control enjoyed by the intended owners }\end{array}$ \\
\hline Cell 13b-16b & BIPV Hierarchy 4: as a Building Component \\
\hline $\begin{array}{l}\text { Cell 13b: Environmental } \\
\text { Benefits }\end{array}$ & $\begin{array}{ll}\text { - } & \text { State the savings in embodied energy } \\
\text { - } & \text { State the environmental impact advantage compared with replaced building materials } \\
\text { - } & \text { State benefits as a type of quasi-modular construction system }\end{array}$ \\
\hline $\begin{array}{l}\text { Cell 14b: Economic } \\
\text { Benefits }\end{array}$ & $\begin{array}{l}\text { - State labor and other aggregated cost savings compared with alternative materials, e.g., bricks or blockwork; } \\
\text { mortar, painting; and separate costs for glazing and associated costs. } \\
\text { - } \quad \text { At an advanced level, carry out a full comparative life cycle analysis with other material alternatives } \\
\text { - } \quad \text { State benefit for government payback if Feed-In-Tariffs (FITs) are regionally available }\end{array}$ \\
\hline Cell 15b: Social Benefits & $\begin{array}{ll}\text { - } & \text { State potential visual impact and energy awareness education on/for the residents in the region } \\
\text { - } & \text { State potential to serve as contemporary green building icon } \\
\text { - } & \text { State other potentials for household energy autonomy }\end{array}$ \\
\hline Cell 16b: Design Benefits & $\begin{array}{l}\text { - } \quad \text { Discuss the aesthetic potential of the project compared with other surrounding modern buildings } \\
\text { - } \quad \text { State potential for multiple integration opportunities on roof or facade } \\
\text { - State multi-functional uses of the BIPV installation: does it provide daylighting or view or shading along with } \\
\text { energy for example. }\end{array}$ \\
\hline
\end{tabular}

It is necessary at this stage to revisit the initial scenario depicted by existing literature and the potential relevance of this investigation. Information and perception have been listed as determinants in the adoption renewable energy project [45] and the balance of economic, technical and environmental benefits is crucial. The matrix represents a simple but clear approach to addressing these issues. It also helps in decision support for renewable technology and energy planning, built on and applying a user-friendly method [51]. The identification of limited awareness of solar energy benefits specifically in rural regions [56] can be addressed by applying the matrix as a simple-to-understand communication tool. It also embraces suggested multidisciplinary approaches and perspectives [48] while raising 
market awareness to its benefits [60]. The results of the pilot UX survey also agree with innovation theorists [68,69], and suggests that knowledge of benefits can promote the rate of adoption of an innovation among likely adopters. The priority given to environmental and economic benefits, over social and design benefits is subjective and is influenced by the perspective of the respondents. Further analysis of respondent or stakeholder type is required to fully understand these results. Nevertheless, the results are in general agreement with other studies on the perceived values attached to BIPV as an environmentally-friendly energy source with potential cost-saving benefits [1,29]. Conclusively, the conceptual approach and the matrix developed, addresses confidence issues in BIPV proposals by providing information, knowledge and access to verifiable information about system benefits.

\section{Future Research}

Having established the conceptual framework in this study, the development, and evaluation of the approach, the next step will be to try it out on an actual BIPV project proposal to aid/test practicality in real-life scenarios. This can be used to showcase the possible advantages and impact of the approach so it can be enhanced or reviewed accordingly. Also, a wider UX survey can be run with the actual approach to compare with the preliminary pilot, evaluate its effectiveness with potential clients, and evaluate stakeholder preferences. These two strategies are in view, and the authors hope to complete them in the near future.

Beyond the scope of this investigation, the discussion on BIPV advantages will continue within various disciplines as more studies validate its applicability towards net zero building $[8,89]$. Aspects of architectural integration, engineering, and manufacturing techniques as well as material technology will continue to develop. Research investigations show strategies for improved energy savings up to $10 \%$ via optimization in specific hot climate conditions [90], and improved power and performance ratio up to $40 \%$ via customization [91,92]. It is likely that investigations like these will continue to drive the rise of high performing BIPV systems in the coming years. However, communicating this technology and presenting its multi-dimensional benefits to all stakeholders will need to be advanced. The concept of educating the public towards advancing an appreciation of advantages will continue to be crucial in sustainability [93]. Within professional circles, university courses, professional development seminars, and communiqués on post-occupancy evaluations of BIPV projects may be used along with media campaigns for the general public to encourage adoption.

\section{Conclusions}

This study discussed the development of a conceptual framework for an educative-communication approach for BIPV market and research proposals. The paper examined various interacting topics in the BIPV literature relating to the importance of the BIPV hierarchy. It highlighted the main pillars of sustainability and applied this in the development of a communication approach. The research also discussed and presented its findings of a pilot UX survey and a checklist to evaluate the approach developed. From the existing body of literature, it is obvious there is no precise recipe for how to communicate the advantages of using solar energy in building design. In each project, the development team, project managers, and architects will have different dynamics, as well as varying or similar design objectives for each. Obsolete knowledge and a lack of understanding about aspects of solar energy, and information on older unappealing and nonfunctional designs need to be readdressed in the light of innovative products and technological development. Obstacles can be addressed through communication-accessible information, good examples, and ideal solutions-which emphasize research-based evidence, promote interest and knowledge sharing, in order to realize high-quality solar energy solutions in architecture [35].

From our findings, understanding environmental and economic benefits proves to be an important driver for people who know the benefits of using solar energy for electricity in homes and are likely adopters. We thus conclude that improving understanding of these benefits using the developed approach can potentially facilitate and encourage BIPV adoption. This study elaborates the need 
and strategies for appropriate dissemination of innovative ideas. The approach and findings can be applied in other contexts, and for other technological breakthroughs or new product development which advance a sustainable global future.

Author Contributions: "Initial Conceptualization" of the investigation was carried out by D.E.A., K.A.T.A., and A.H.; "Investigation and Methodology" was carried out by D.E.A. and T.O.A.; "Supervision" of the text was carried out by K.A.T.A. and A.H. "Statistical analysis" was carried out by T.O.A. The "Evaluation" section was developed and executed by S.O.A., D.E.A., and T.O.A.; "Writing" of the original draft was carried out by D.E.A. and T.O.A.; "Writing review and editing" was carried out by all the authors.

Funding: This research was funded in part by the UAE University (UAEU).

Acknowledgments: The authors appreciate the support given by the UAE University (UAEU).

Conflicts of Interest: The authors declare no conflict of interest.

\section{References}

1. Jelle, B.P. Building integrated photovoltaics: A concise description of the current state of the art and possible research pathways. Energies 2016, 9, 21. [CrossRef]

2. Radhi, H. On the value of decentralised PV systems for the GCC residential sector. Energy Policy 2011, 39, 2020-2027. [CrossRef]

3. Hiremath, R.B.; Shikha, S.; Ravindranath, N.H. Decentralized energy planning; modeling and application-A review. Renew. Sustain. Energy Rev. 2007, 11, 729-752. [CrossRef]

4. Banos, R.; Manzano-Agugliaro, F.; Montoya, F.G.; Gil, C.; Alcayde, A.; Gómez, J. Optimization methods applied to renewable and sustainable energy: A review. Renew. Sustain. Energy Rev. 2011, 15, 1753-1766. [CrossRef]

5. Toledo, O.M.; Oliveira Filho, D.; Diniz, A.S.A.C. Distributed photovoltaic generation and energy storage systems: A review. Renew. Sustain. Energy Rev. 2010, 14, 506-511. [CrossRef]

6. Sauter, R.; Watson, J. Strategies for the deployment of micro-generation: Implications for social acceptance. Energy Policy 2007, 35, 2770-2779. [CrossRef]

7. Dunn, S.; Peterson, J.A. Micropower: The Next Electrical Era; Worldwatch Institute: Washington, DC, USA, 2000.

8. Kylili, A.; Fokaides, P.A. Investigation of building integrated photovoltaics potential in achieving the zero energy building target. Indoor Built Environ. 2014, 23, 92-106. [CrossRef]

9. Bonomo, P.; Chatzipanagi, A.; Frontini, F. Overview and analysis of current BIPV products: New criteria for supporting the technological transfer in the building sector. VITRUVIO-Int. J. Arch. Technol. Sustain. 2015, 67-85. [CrossRef]

10. Designing Photovoltaic Systems for Architectural Integration. Available online: http://task41.iea-shc.org/ data/sites/1/publications / task41A3-2-Designing-Photovoltaic-Systems-for-Architectural-Integration. pdf (accessed on 1 April 2018).

11. Montoro, D.F.; Vanbuggenhout, P.; Ciesielska, J. Building Integrated Photovoltaics: An Overview of the Existing Products and Their Fields of Application; Report Prepared in the Framework of the European Funded Project; SUNRISE: Saskatoon, SK, Canada, 2011.

12. Heinstein, P.; Ballif, C.; Perret-Aebi, L.-E. Building integrated photovoltaics (BIPV): Review, potentials, barriers and myths. Green 2013, 3, 125-156. [CrossRef]

13. Energy Systems in Architecture-Integration Criteria and Guidelines. Available online: https://infoscience. epfl.ch/record/197097 / files/T41DA2-Solar-Energy-Systems-in-Architecture-28March20131.pdf (accessed on 1 April 2018).

14. Jelle, B.P.; Breivik, C.; Røkenes, H.D. Building integrated photovoltaic products: A state-of-the-art review and future research opportunities. Sol. Energy Mater. Sol. Cells 2012, 100, 69-96. [CrossRef]

15. Scognamiglio, A.; Farkas, K.; Frontini, F.; Maturi, L. Architectural quality and photovoltaic products. In Proceedings of the 27th European Photovoltaic Solar Energy Conference and Exhibition (EU PVSEC), Frankfurt, Germany, 24-28 September 2012; pp. 24-28.

16. Thomas, R. What are photovoltaics? In Photovoltaics and Architecture; Taylor \& Francis: London, UK, 2003; pp. 18-28. 
17. Morton, O. Solar Energy: A New Day Dawning? Silicon Valley Sunrise; Nature Publishing Group: London, UK, 2006.

18. Lewis, N.S.; Nocera, D.G. Powering the planet: Chemical challenges in solar energy utilization. Proc. Natl. Acad. Sci. USA 2006, 103, 15729-15735. [CrossRef] [PubMed]

19. Bakos, G.C.; Soursos, M.; Tsagas, N.F. Technoeconomic assessment of a building-integrated PV system for electrical energy saving in residential sector. Energy Build. 2003, 35, 757-762. [CrossRef]

20. Sharples, S.; Radhi, H. Assessing the technical and economic performance of building integrated photovoltaics and their value to the GCC society. Renew. Energy 2013, 55, 150-159. [CrossRef]

21. Timilsina, G.R.; Kurdgelashvili, L.; Narbel, P.A. Solar energy: Markets, economics and policies. Renew. Sustain. Energy Rev. 2012, 16, 449-465. [CrossRef]

22. Van Sark, W.G.J.H.M.; Arancon, S.; Weiss, I.; Tabakovic, M.; Fechner, H.; Louwen, A.; Georghiou, G.; Makrides, G. Development of BIPV courseware for students and professionals: The Dem4BIPV Project. In Proceedings of the 33rd European Photovoltaic Solar Energy Conference, Amsterdam, The Netherlands, 28 September 2017; pp. 2895-2899.

23. Sawin, J. Renewable Energy Policy Network for the 21st Century Renewables 2017 Global Status Report; REN21 Secretariat: Paris, France, 2017; pp. 1-302.

24. IEA PVPS. Snapshot of Global Photovoltaic Markets; Report IEA PVPS T1-31. 2017. Available online: http://www.iea-pvps.org/fileadmin/dam/public/report/statistics/IEA-PVPS_-_A_Snapshot_ of_Global_PV_-_1992-2016__1_.pdf (accessed on 1 April 2018).

25. Ritzen, M.; Reijenga, T.; El Gammal, A.; Warneryd, M.; Sprenger, W.; Rose-Wilson, H.; Payet, J.; Morreau, V.; Boddaert, S. IEA-PVPS Task 15: Enabling Framework for BIPV Acceleration (IEA-PVPS). In Proceedings of the 48th IEA PVPS Executive Commitee Meeting, Vienna, Austria, 15-16 November 2016; Volume 16.

26. Prieto, A.; Knaack, U.; Auer, T.; Klein, T. Solar façades-Main barriers for widespread façade integration of solar technologies. J. Façade Des. Eng. 2017, 5, 51-62.

27. Tabakovic, M.; Fechner, H.; Van Sark, W.; Louwen, A.; Georghiou, G.; Makrides, G.; Loucaidou, E.; Ioannidou, M.; Weiss, I.; Arancon, S. Status and outlook for building integrated photovoltaics (BIPV) in relation to educational needs in the BIPV sector. Energy Procedia 2017, 111, 993-999. [CrossRef]

28. Goh, K.C.; Goh, H.H.; Yap, A.B.K.; Masrom, M.A.N.; Mohamed, S. Barriers and drivers of Malaysian BIPV application: Perspective of developers. Procedia Eng. 2017, 180, 1585-1595. [CrossRef]

29. Yang, R.J.; Zou, P.X. Building integrated photovoltaics (BIPV): Costs, benefits, risks, barriers and improvement strategy. Int. J. Constr. Manag. 2016, 16, 39-53. [CrossRef]

30. Karakaya, E.; Sriwannawit, P. Barriers to the adoption of photovoltaic systems: The state of the art. Renew. Sustain. Energy Rev. 2015, 49, 60-66. [CrossRef]

31. Yang, R.J. Overcoming technical barriers and risks in the application of building integrated photovoltaics (BIPV): Hardware and software strategies. Autom. Constr. 2015, 51, 92-102. [CrossRef]

32. Mousa, O. BIPV/BAPV Barriers to Adoption: Architects' Perspectives from Canada and the United States. Master's Thesis, University of Waterloo, Waterloo, ON, Canada, 2014.

33. Azadian, F.; Radzi, M.A.M. A general approach toward building integrated photovoltaic systems and its implementation barriers: A review. Renew. Sustain. Energy Rev. 2013, 22, 527-538. [CrossRef]

34. Koinegg, J.; Brudermann, T.; Posch, A.; Mrotzek, M. It Would Be a Shame if We Did Not Take Advantage of the Spirit of the Times.... An Analysis of Prospects and Barriers of Building Integrated Photovoltaics. GAIA-Ecol. Perspect. Sci. Soc. 2013, 22, 39-45. [CrossRef]

35. Probst, M.M.; Roecker, C. Criteria for architectural integration of active solar systems IEA Task 41, Subtask A. Energy Procedia 2012, 30, 1195-1204. [CrossRef]

36. Taleb, H.M.; Pitts, A.C. The potential to exploit use of building-integrated photovoltaics in countries of the Gulf Cooperation Council. Renew. Energy 2009, 34, 1092-1099. [CrossRef]

37. Attoye, D.E.; Tabet Aoul, K.A.; Hassan, A. A Review on Building Integrated Photovoltaic Façade Customization Potentials. Sustainability 2017, 9, 2287. [CrossRef]

38. International Renewable Energy Agency (IRENA). Renewable Power Generation Costs in 2017; IRENA: Abu Dhabi, United Arab Emirates, 2018.

39. Nejat, P.; Jomehzadeh, F.; Taheri, M.M.; Gohari, M.; Majid, M.Z.A. A global review of energy consumption, $\mathrm{CO} 2$ emissions and policy in the residential sector (with an overview of the top ten $\mathrm{CO} 2$ emitting countries). Renew. Sustain. Energy Rev. 2015, 43, 843-862. [CrossRef] 
40. World Energy Council (WEC). World Energy Resources 2013 Survey; World Energy Council: London, UK, 2013.

41. A Call to Action: Buildings Key to Corporate Sustainability. Available online: https://www. environmentalleader.com/2008/09/a-call-to-action-buildings-key-to-corporate-sustainability/ (accessed on 20 August 2018).

42. Hagemann, I.B. Examples of successful architectural integration of PV: Germany. Prog. Photovolt. Res. Appl. 2004, 12, 461-470. [CrossRef]

43. Blessing, L.T.; Chakrabarti, A. DRM, a Design Research Methodology; Springer Science \& Business Media: New York, NY, USA, 2009.

44. Yin, R.K. Case Study Research and Applications: Design and Methods; Sage Publications: London, UK, 2017.

45. Eisenhardt, K.M.; Graebner, M.E. Theory building from cases: Opportunities and challenges. Acad. Manag. J. 2007, 50, 25-32. [CrossRef]

46. Stigka, E.K.; Paravantis, J.A.; Mihalakakou, G.K. Social acceptance of renewable energy sources: A review of contingent valuation applications. Renew. Sustain. Energy Rev. 2014, 32, 100-106. [CrossRef]

47. Hansen, J.P.; Narbel, P.A.; Aksnes, D.L. Limits to growth in the renewable energy sector. Renew. Sustain. Energy Rev. 2017, 70, 769-774. [CrossRef]

48. Kabir, E.; Kumar, P.; Kumar, S.; Adelodun, A.A.; Kim, K.-H. Solar energy: Potential and future prospects. Renew. Sustain. Energy Rev. 2018, 82, 894-900. [CrossRef]

49. Hernandez, R.R.; Easter, S.B.; Murphy-Mariscal, M.L.; Maestre, F.T.; Tavassoli, M.; Allen, E.B.; Barrows, C.W.; Belnap, J.; Ochoa-Hueso, R.; Ravi, S. Environmental impacts of utility-scale solar energy. Renew. Sustain. Energy Rev. 2014, 29, 766-779. [CrossRef]

50. Singh, G.K. Solar power generation by PV (photovoltaic) technology: A review. Energy 2013, 53, 1-13. [CrossRef]

51. Kandpal, T.C.; Broman, L. Renewable energy education: A global status review. Renew. Sustain. Energy Rev. 2014, 34, 300-324. [CrossRef]

52. Strantzali, E.; Aravossis, K. Decision making in renewable energy investments: A review. Renew. Sustain. Energy Rev. 2016, 55, 885-898. [CrossRef]

53. Panwar, N.L.; Kaushik, S.C.; Kothari, S. Role of renewable energy sources in environmental protection: A review. Renew. Sustain. Energy Rev. 2011, 15, 1513-1524. [CrossRef]

54. Thirugnanasambandam, M.; Iniyan, S.; Goic, R. A review of solar thermal technologies. Renew. Sustain. Energy Rev. 2010, 14, 312-322. [CrossRef]

55. Bazilian, M.; Onyeji, I.; Liebreich, M.; MacGill, I.; Chase, J.; Shah, J.; Gielen, D.; Arent, D.; Landfear, D.; Zhengrong, S. Re-considering the economics of photovoltaic power. Renew. Energy 2013, 53, 329-338. [CrossRef]

56. Solangi, K.H.; Islam, M.R.; Saidur, R.; Rahim, N.A.; Fayaz, H. A review on global solar energy policy. Renew. Sustain. Energy Rev. 2011, 15, 2149-2163. [CrossRef]

57. Kannan, N.; Vakeesan, D. Solar energy for future world-A review. Renew. Sustain. Energy Rev. 2016, 62, 1092-1105. [CrossRef]

58. Khan, J.; Arsalan, M.H. Solar power technologies for sustainable electricity generation-A review. Renew. Sustain. Energy Rev. 2016, 55, 414-425. [CrossRef]

59. Hafez, A.Z.; Soliman, A.; El-Metwally, K.A.; Ismail, I.M. Tilt and azimuth angles in solar energy applications-A review. Renew. Sustain. Energy Rev. 2017, 77, 147-168. [CrossRef]

60. Lewis, N.S. Research opportunities to advance solar energy utilization. Science 2016, 351, aad1920. [CrossRef] [PubMed]

61. Sampaio, P.G.V.; González, M.O.A. Photovoltaic solar energy: Conceptual framework. Renew. Sustain. Energy Rev. 2017, 74, 590-601. [CrossRef]

62. Parida, B.; Iniyan, S.; Goic, R. A review of solar photovoltaic technologies. Renew. Sustain. Energy Rev. 2011, 15, 1625-1636. [CrossRef]

63. Jäger-Waldau, A. European Photovoltaics in world wide comparison. J. Non-Cryst. Solids 2006, 352, $1922-1927$. [CrossRef]

64. Feltrin, A.; Freundlich, A. Material considerations for terawatt level deployment of photovoltaics. Renew. Energy 2008, 33, 180-185. [CrossRef] 
65. Luthander, R.; Widén, J.; Nilsson, D.; Palm, J. Photovoltaic self-consumption in buildings: A review. Appl. Energy 2015, 142, 80-94. [CrossRef]

66. Zomer, CD.; Costa, M.R.; Nobre, A.; Rüther, R. Performance compromises of building-integrated and building-applied photovoltaics (BIPV and BAPV) in Brazilian airports. Energy Build. 2013, 66, 607-615. [CrossRef]

67. Sahin, I. Detailed review of Rogers' diffusion of innovations theory and educational technology-related studies based on Rogers' theory. Turk. Online J. Educ. Technol. 2006, 5, 14-23.

68. Rogers, E.M. Diffusion of Innovations, 5th ed.; A Division of Macmillan Publishing Co Inc.: New York, NY, USA; Free Press: New York, NY, USA, 2003.

69. Wisdom, J.P.; Chor, K.H.B.; Hoagwood, K.E.; Horwitz, S.M. Innovation adoption: A review of theories and constructs. Adm. Policy Ment. Health Ment. Health Serv. Res. 2014, 41, 480-502. [CrossRef] [PubMed]

70. Yin, R.K. Discovering the future of the case study. Method in evaluation research. Eval. Pract. 1994, 15, 283-290. [CrossRef]

71. Eisenhardt, K.M. Better stories and better constructs: The case for rigor and comparative logic. Acad. Manag. Rev. 1991, 16, 620-627. [CrossRef]

72. Shakir, M. The Selection of Case Studies: Strategies and Their Applications to IS Implementation Case Studies; Massey University: Palmerston North, New Zealand, 2002.

73. Siggelkow, N. Persuasion with case studies. Acad. Manag. J. 2007, 50, 20-24. [CrossRef]

74. The Communication Process. Available online: https://infoscience.epfl.ch/record/197100/files/T41C1CommunicationsGuide-2012.pdf (accessed on 1 April 2018).

75. Espeche, J.M.; Noris, F.; Lennard, Z.; Challet, S.; Machado, M. PVSITES: Building-integrated photovoltaic technologies and systems for large-scale market deployment. Multidiscip. Digit. Publ. Inst. Proc. 2017, 1, 690. [CrossRef]

76. Femenías, P.; Thuvander, L.; Gustafsson, A.; Park, S.; Kovacs, P. Improving the market up-take of energy producing solar shading: A communication model to discuss preferences for architectural integration across different professions. In Proceedings of the 9th Nordic Conference on Construction Economics and Organization, Göteborg, Sweden, 13-14 June 2017; Volume 13, p. 140.

77. PVSITES Project. BIPV Demo Sites. Available online: http://www.pvsites.eu/project/demo-sites/ (accessed on 20 August 2018).

78. Parris, T.M.; Kates, R.W. Characterizing and measuring sustainable development. Annu. Rev. Environ. Resour. 2003, 28, 559-586. [CrossRef]

79. Beccali, M.; Cellura, M.; Mistretta, M. Decision-making in energy planning. Application of the Electre method at regional level for the diffusion of renewable energy technology. Renew. Energy 2003, 28, 2063-2087. [CrossRef]

80. Terrados, J.; Almonacid, G.; PeRez-Higueras, P. Proposal for a combined methodology for renewable energy planning. Application to a Spanish region. Renew. Sustain. Energy Rev. 2009, 13, 2022-2030. [CrossRef]

81. Disley, Y.P. Sustainable development goals for people and planet. Nature 2013, 495, 305-307.

82. Kumar, A.; Sah, B.; Singh, A.R.; Deng, Y.; He, X.; Kumar, P.; Bansal, R.C. A review of multi criteria decision making (MCDM) towards sustainable renewable energy development. Renew. Sustain. Energy Rev. 2017, 69, 596-609. [CrossRef]

83. The Future of Sustainability: Re-thinking Environment and Development in the Twenty-first Century. Available online: https://cmsdata.iucn.org/downloads/iucn_future_of_sustanability.pdf (accessed on 1 April 2018).

84. United Nations. World Summit Outcome. Available online: http://www.un.org/womenwatch/ods/ARES-60-1-E.pdf (accessed on 1 April 2018).

85. Robert, K.W.; Parris, T.M.; Leiserowitz, A.A. What is sustainable development? Goals, indicators, values, and practice. Environ. Sci. Policy Sustain. Dev. 2005, 47, 8-21. [CrossRef]

86. Attoye, D.E.; Tabet Aoul, K.A.; Hassan, A. Development of A Building Integrated Photovoltaics-Mass Custom Housing. In Proceedings of the 5th Zero Energy Mass Custom Homes International Conference, Kuala Lumpur, Malaysia, 20-23 December 2016; pp. 142-152.

87. International Standards Organization. ISO 9241-210: Ergonomics of Human System Interaction-Part 210: Human-Centred Design for Interactive Systems; International Organization for Standardization (ISO): Geneva, Switzerland, 2008. 
88. Hassenzahl, M.; Tractinsky, N. User experience-a research agenda. Behav. Inf. Technol. 2006, 25, 91-97. [CrossRef]

89. Baetens, R.; De Coninck, R.; Van Roy, J.; Verbruggen, B.; Driesen, J.; Helsen, L.; Saelens, D. Assessing electrical bottlenecks at feeder level for residential net zero-energy buildings by integrated system simulation. Appl. Energy 2012, 96, 74-83. [CrossRef]

90. Al Dakheel, J.; Tabet Aoul, K.; Hassan, A. Enhancing Green Building Rating of a School under the Hot Climate of UAE; Renewable Energy Application and System Integration. Energies 2018, 11, 2465. [CrossRef]

91. Nagy, Z.; Svetozarevic, B.; Jayathissa, P.; Begle, M.; Hofer, J.; Lydon, G.; Willmann, A.; Schlueter, A. The adaptive solar facade: From concept to prototypes. Front. Arch. Res. 2016, 5, 143-156. [CrossRef]

92. Valckenborg, R.M.E.; van der Wall, W.; Folkerts, W.; Hensen, J.L.M.; de Vries, A. Zigzag Structure in Façade Optimizes PV Yield While Aesthetics are Preserved. In Proceedings of the 32nd European Photovoltaic Solar Energy Conference and Exhibition, Munich, Germany, 20-24 June 2016; European Commission: Brussels, Belgium; pp. 647-650.

93. Adekunle, T.O. Autonomous Living: An Eco-social Perspective. Int. J. Constr. Environ. 2015, 6, 1-15. [CrossRef]

(C) 2018 by the authors. Licensee MDPI, Basel, Switzerland. This article is an open access article distributed under the terms and conditions of the Creative Commons Attribution (CC BY) license (http://creativecommons.org/licenses/by/4.0/). 